\title{
Exploring Challenges Experienced by Physically Challenged Students at A Further Education and Training College in Kwazulu-Natal Province
}

\author{
Dr Mabatho Sedibe \\ Department of Educational Psychology, University of Johannesbur, \\ Auckland-park, Johannesburg 2006, South Africa \\ Email:mabathos@uj.ac.za \\ Mr Michael M.Buthelezi \\ Senior Lecturer at Majuba Further Education \\ Training College in KwaZulu-Natal province. Mathematics Department \\ Email: 45128197@mylife.unisa.ac.za
}

\section{Doi:10.5901/jesr.2014.v4n3p421}

\begin{abstract}
This study is based on exploring challenges experienced by physically challenged students at a Further Education and Training College in Kwa-Zulu Natal Province. The study intends to give an overview of results concerning challenges experienced by physically challenged students at a Further Education and Training College with special reference to Kwa-Zulu Natal Province. Qualitative method was used in this study and data was collected through observation and interviews where physically challenged students at that FET were the participants. The findings showed that such students are not yet catered for in as far as facilities are concerned, yet White Paper Six encourages inclusive Education.
\end{abstract}

Keywords: Further Education and Training, Colleges, Physically Challenged Students and Facilities.

\section{Introduction and the Background of the Study}

Mango Further Education and Training College (FET) College is situated at Newcastle, in the Northern part of KwaZuluNatal Province. Mango FET College has six campuses. Information Technology and Business (ITB) Campus offers Report 191 business studies programs, N4 to N6 as well as the National Vocational in Hospitality, Finance, Economics and Accounting, Information Technology and Computer Science. The campus had 750 students according to the college of technology (coltech) of 2012. College of technology system is the system that is used at FET Colleges to enter the following: students' enrolments, personal information, registration information, guardian information, school information and medical information of each student Five percent of the students are physically challenged. Most of these students were from disadvantaged background and by being disadvantaged it implied that they were from poor families. The college did not have educational resources for physically challenged students such as adequate toilet facilities and accessible buildings. Lecturers at Mango FET College did not receive in-service training regarding students ' challenges, availability of resources and the explanation of the appropriate developmental needs of disabled students.

The college had tried to train lecturers in terms of assessment, facilitation and moderation, but there was still a gap when it came to training them about teaching physically challenged students. Physically challenged students did not receive education which was specifically geared to their particular problems. In other words lecturers did not have adequate knowledge about counselling needs of students with physical disabilities and their parents. The lack of knowledge was caused by not receiving training about physical disability. In terms of counselling, the college had employed full time counsellors for each campus. Lecturers, parents, peers and community`s attitude towards physical disability was the main cause for physically challenged students to withdraw from interaction with them and cease trying to be independent.

As a result, these students became drop-outs and did not finish the National Certificate Vocational (NCV) programmes. The college did not have enough assistance and support which would accomplish tasks that never thought possible a decade ago. There were no planned interventions and programmes which took into account that these students had the right to their own choices to choose their destiny and allowed the individual personal power in their 
lives. Physically challenged students were thus not fully motivated at Mango FET College.

\section{Problem Statement}

Buuren (1990) cites that the inadequacy of basic health screening in schools is of immediate concern to him and many physical health problems which are easily treated if they are picked up at school have been left unidentified and untreated. Donald (1994) further adds that most of the learners with physical disabilities are under conditions of poverty social disadvantage. That is true in a sense that most physically challenged students at Mango FET College were from the poor families and that made them not perform very well. Kapp (1991) also argues that many of the tasks for the individuals with physical disability may be caused more by a lack of resources rather than individual lack of skill or will. This was the same problem at Mango FET College. These socio-economic disadvantages resulted in a high rate of absenteeism which impacted negatively on students' performance levels.

Terre Blanche (2004) also indicates that the development of a community requires careful collaboration with community members and the tapping of local knowledge. The college did not fully involved parents of physically challenged students. According to Nsamenang (2004), the family is an important structure as it has the foundation for a child's development even before the child is born and it prepares the child to acquire skills in interpersonal processes and communication. Thus a family is the secure base on which students should build the confidence needed to relate to others and the world.

The researcher agreed with Nsamenang (2004) in the sense that students with physical disabilities at Mango FET College were not fully assisted by their parents and lecturers in terms of educational support and motivation. These students with physical disabilities often had a poor self- image, which resulted in the formation of the negative selfconcept. These feelings of poor self-esteem resulted in an inferior complex which had a negative impact towards their academic achievements and social development. Morrow (1985) argues that these thoughts make the child feels that he or she is a burden, no good, not wanted, a disgrace or untouchable. This caused a distance between physically disabled students and other students. The barrier of others` attitudes however remained high.

Friendships and relationships with other students remain difficult according to Kneedler, Hallahan and Kauffman (1984). Consequently students with physical challenges at Mango FET College experienced socializing problems especially in mainstream education. The concept of one's should be closely related to both the capabilities and limitations of the both structure, so that internal motivation will be realistically related to one's disabilities. Kapp (1991) argues that physically disabled learners generally experience problems with mobility. Access to building at particular areas may cause problems. Where no special provision is made, certain buildings and areas remain inaccessible for physically challenged students in schools. The researcher also agreed with Kapp (1991) that access to college building in Mango FET College was a problem for physically challenged students. Mango FET College was a double storey building with no proper stairs for physically challenged students. Macleod (1998) states that specific learning needs of physically disabled learners in a disadvantaged social context are likely to be made worse by inadequate resources. Donald and Green (1995) also argue that equally the number of learners with specific learning needs puts additional pressure on poor educational and social resources so that the entire context tends to get worse. Donald and Green (1995) further cite that educators are not given in-service training regarding various handicaps, the availability of resources for learners and the explanation of the appropriate psychosocial needs of disabled learners in schools.

Mango FET College had the same problems of not having resources for physically challenged students, for example, there were no toilets and ramps for physically challenged students. Yet the college was enrolling these physically challenged students as mentioned in the preceding sections. Hosie (1982) argues that to solve these problems, educators should learn the counselling needs of learners with physical disabilities and their parents. The college was not providing lecturers with education about counselling needs of physically challenged students.

Kapp (1991) states that physically disabled learners require education which is specifically geared to their particular problems and potentialities. Parents therefore should play a role in the mainstreaming learners with physical disabilities. It is also true that a child 's development is disrupted when family life has failed to prepare life or when school life fails to sustain the promises of earlier stages. Baumberger and Harper (2007), note that students with disabilities often need assistance in acquiring skills for independent living. Students with physical disabilities at Mango FET College suffered from discrimination and judgment of others; sometimes simply for the peculiar but harmless ways they conducted themselves. 


\section{Research Question}

Based on the above discussion, the following main research question was thus being asked:

- What are the challenges experienced by physically challenged students at Mango FET College in KwaZuluNatal Province?

\subsection{Research sub-questions}

- What are the challenges experienced by physically challenged students at Mango FET College in KwaZuluNatal Province?

- What guidelines are used by lecturers to assist physically challenged students at Mango FET College in KwaZulu-Natal Province?

\section{The Aim of the Study}

The aim of this study was to explore and describe the challenges experienced by physically challenged students at Mango Further Education and Training college in KwaZulu-Natal Province.

The objectives of this study were to:

- Identify challenges experienced by physically challenged students at Mango Further Education and Training College in KwaZulu-Natal Province.

- Find the possible guidelines to be used by the lecturers at Mango Further education and Training College in KwaZulu-Natal Province to assist physically challenged students.

\section{Research Design and Methodology}

The study was conducted from the interpretive paradigm. According to Terre Blanche and Durrheim (1999), paradigms act as perspectives that provide a rationale for the research, and commit the researcher to particular methods of data collection, observation and interpretation. The aim was to discover challenges experienced by physically challenged students at the FET college. An interpretive paradigm in this study refers to a concern in exploring and understanding the social world using both the participants` and the researcher`s understandings (Ritchie and Lewis, 2003).

In this study qualitative research method was used. Denzin and Lincoln (1994) state that qualitative research method implies an emphasis on processes and meanings that are not rigorously examined or measured in terms of quantity, amount, intensity or frequency. Silverman (2000) further mentions that the method used by qualitative researchers represents a common belief that they can provide a deeper understanding of the social phenomenon under investigation.

\section{Purposive Sampling}

Merriam (1998) clarifies that purposive sampling is based on the assumption that the researcher wants to understand a phenomenon and must, therefore, purposefully select participants who are rich in information regarding the phenomenon. Therefore, participants included should be knowledgeable, willing to participate and readily available (Greyling, 2008). Furthermore, purposive sampling takes place when the group of participants is homogenous, sharing the experience of a particular situation (Willing, 2001). In this study, participants are thus physically challenged students at an FET college.

\section{Data Collection}

Data collection is the technique employed in research, to gather information from the phenomena under the study and draw a meaningful understanding in accordance with research question. Merriam (2002), defines the concept data as: bits and pieces of information found in the environment that are collected in systematic ways to provide an evident base from which to make interpretation and statements intended to advance knowledge and understanding concerning a research question or problem. Leedy and Ormrod (2005), state that "qualitative researchers often use multiple forms of data techniques that suits well with the research questions". In this study the researcher therefore used observations and interviews as the main tools for data collection. 


\subsection{Observation}

Atkinson and Hammersley (in Denzin and Lincoln, 1994) define observation as a 'systematic data collection approach'. According to Fetterman (1998) participant observation combines participation in the lives of the people being studied with maintenance of a professional distance that allows adequate observation and recording of data. Observation was appropriate and was used for this study because the researcher observed the interactions of the participants involved as detached outsiders but experienced them first hand as insiders.

Maxwell (2005) supported the above statement by saying that "observation can enable you to draw inferences about the perspectives that you could not obtain by relying exclusively on interview data.

\subsection{Interviews}

Interviews were used in order to see to it that all the relevant topics regarding the research study's focus were covered during the interview session (Patton, 2002), but also allowed for greater flexibility in exploring the experiences of physically challenged students at the FET college. Some of the following questions were asked during the interviews:

- What do you think about learner support from student support services and from the college?

- If there are no supports, how you think should be provided and how you think can assist you to cope academically?

- Do you think that there are adequate resources for physically challenged students at the college? If there are, name them and if there is none, what you personally think should be done?

- What can you say about buildings at the college?

- Do you think they are accessible for physically challenged students? If you think they are not, suggest things that should be done and who should do those things?

- In terms of support from parents of physically challenged students, tell me the support/s you receive from them.

- In what ways do you receive it, if you receive it and what are you suggestions concerning support from parents?

\section{Discussion of the Findings}

The discussion is based on the study's significant findings as revealed in the previous chapter, and contextualised them against the existing bodies of literature. Some of the findings are tabled and discussed below:

\subsection{The factors affecting the academic development of physically challenged students at FET college in Kwa-Zulu Natal Province.}

The factors that affected the academic development of physically challenged students at Mango FET College in KwaZulu-Natal Province were gleaned from the this study and it stood out as important to this study's research participants include: the lack of support from student support services and from FET college, the lack of resources, the inaccessibility of buildings and inadequate support from parents of physically challenged students. The above-mentioned constituent factors were discussed in the proceeding section.

Department of Education (2001) argue that limited attention has been placed on addressing issues of access and participation for students categorised by government's National Plan for Higher Education (NPHE) as non- traditional students. Both the South African disability movement and the South African government approach disability from a social model. As such their policy documents firmly state that institutions need to accommodate physical students and remove barriers that hinder their developments. Included within this category are physically challenged students who are recognised in the policy framework as having been historically disadvantaged, and as an important target group to reach in broadening the social base of the further or higher education system. For physically challenged students, inequalities in FET colleges began with inequalities that had shaped the whole college system in South Africa. The lack of appropriate and adequate provision for physically challenged students at the college and school level had profoundly affected access to higher education for physically challenged students. It was important to recognise that although, as already stated the South African higher education policy framework had a strong equity agenda which included physically challenged students, the policy also warns against institutions recruiting students who do not have the potential to pursue 
further study and that they do not retain students who have no chance of success according to Department of Education (2001).

Naidoo (2010) argues that adequate systems need to be put in place to ensure that institutional and appropriate curricula transformation occurs and support is provided. Although legislation required FET colleges to include students with physical disabilities, on ground level, appropriate practice was necessary to ensure that physically challenged students in fact got support and accommodation they needed in order to participate equally.

\subsection{The lack of support from students support services at FET college in Kwa-Zulu Natal Province.}

All the participants from this study voiced their views of the lack of support from students support services and from Mango FET College, which they reported, put them at great disadvantage in terms of meeting their academic as well as emotional and social needs. This had affected their academic development. In light of the above, Fuller, Healey, Bradley and Hall (2004) caution us against talking of physical disabilities as though they are homogenous group. Students with physical disabilities have diverse needs. Gewer (2010) cites that there is limited knowledge on the effectiveness of learner support services within colleges. Gewer (2010) further states that where there are services they are not being utilised by the students and lecturers. Even the data from a survey of national certificate vocational (NCV) students at FET Colleges in 2009 suggested that there were limited learner support services available.

Participants also reported that they did not have access to counselling facilities and no one was talking about their physical disabilities. Participants mentioned that Disability Support Services should have been available at the college. It was also reported that having no disability support services had harmful effects on the emotional state of physically challenged students. With regard to counselling, the college had tried to hire some counsellors, but there was still a shortage of counsellors at the college according to the participants. The college needed to hire more counsellors that were trained for each campus. Participants also reported that lecturers that were members of students support services were not fully trained to deal with physically challenged students.

Participants also voiced the issue of lecturers who were not receiving in-service training in as far as physical challenges were concerned. All stakeholders such as lecturers, students support services, counsellors, student representative council and the college reported by participants should play a major role in assisting physically challenged students. Participants also reported that having no ramps at the college for physically challenged students had a negative impact on their academic development. Department of Education (1997) states the following as barriers to learning: inaccessible environments for example, the lack of ramps in education schools and harmful and negative attitudes towards learners with physical disabilities making these students more vulnerable and more likely to be excluded or to experience learning breakdown.

\subsection{Inadequate support from parents of physically challenged students at Mango FET College and the meaning of physical disabilities for parents.}

Most of the participants reported that there was not much role that was played by parents in the education of physically challenged students at Mango FET College. Lecturers complained about parents not attending parents' meetings at the college. Allen and Cowdery (2009) stress that regular parent conference or meetings should be scheduled two or three times a year to build a good working relationship between lecturers and parents of physically challenged students.

Parents of students with physical disabilities are faced with disappointments and adjustments according to Allen and Cowdery (2009). Inadequate support from parents made it difficult for physically challenged students to cope and develop academically. Participants also viewed that parents of physically challenged students lacked understanding and training about physical disabilities. Participants also suggested that parents should be trained by the college in order to meet their children` needs.

The findings from this study revealed that there were many barriers experienced by physically challenged students at Mango FET College in KwaZulu-Natal Province. The following factors affected the academic development of physically challenged students at Mango FET College: lack of support from students support services and from the college, lack of resources for physically challenged students at Mango FET College, inaccessibility of buildings for physically challenged students at Mango FET College and inadequate support from parents of physically challenged students at Mango FET College. The researcher was also able to identify these barriers that hindered the academic development of physically challenged students and put these students at a disadvantage to excel academically and socially. When the researcher heard the views of participants, the researcher hoped and believed that positive change should be made through the 
findings from this study for barriers to be overcome.

\section{Conclusion}

From the above discussion, the study points to the possibility that the key role players such as students support services and the college management were firstly not made aware of the physically challenged students and their unique requirements and those that were aware did not seem to be doing their level best to assist these students in order to meet their needs. The college had employed one councillor for each campus, but that was not enough since they were not qualified to counsel these physically challenged students. They were fully trained to aid physically challenged students. Though, there was students support services in place for students, the college did not provide them with proper training in order to assist physically challenged students. Physically challenged students at the college were marginalised. As a result, they did not cope academically and socially. The Students Support Services together with lecturers and college management should have played a major role in supporting physically challenged students by creating an environment where these students could experience attitudes of embracing diversity and accommodating differences. The progress could be made through the increased learner support from students support services and the college management, accessibility of buildings for physically challenged students and roles of parents of physically challenged students.

\section{Recommendations}

Based on the preceding section on discussion and interpretation of the research findings, the following recommendations are thus made that:

- Disability unit hosts teaching workshops to sensitise and educate University lecturers about teaching disabled students, organises a disability awareness week to create awareness among University population, encourages Disability Unit students to introduce themselves to and liaise with their lectures.

- Buildings should be designed in such a way that could be used equitably by all students including physically challenged students.

\section{References}

Allen, K. E. and Cowdery, G.E. (2009). The exceptional child: Inclusive in early childhood education.6th edition. USA: Cengage learning. Atkinson, P. and Hammersley, M. (Eds) (1994). "Ethnography \& participant observation." In NK Denzin and YS Lincoln, Handbook of Qualitative Research (pp. 248-261). Thousand Oaks, CA: Sage Publications.

Baumberger, J.P. and Harper, R.E. (2007). Assisting students with disabilities: A handbook for school counselors. 2nd edition, California: Corwin Press, INC.

Bronfenbrenner, U. (2005). Making human beings human: Bioecological Perspectives on human development, Thousand Oaks, CA: Sage Publications.

Creswell, J.W. (1998). Qualitative Inquiry and Research Design: Choosing Among Five Traditions, Thousand Oaks, California: Sage Publications.

Denzin, N.K. and Lincoln, Y.S. (Ed) (1994). Handbook of qualitative research, California: Sage Publications.

Department of education. (1997d). Quality education for all. Report of the National Commission of Special Education Needs and Training, Pretoria: Government Printers.

Donald, D. (1994). Children with special education needs: The Reproduction of Disadvantage in Poorly Served Communities, Cape Town: Oxford University Press Southern Africa.

Fetterman, D.M. (1998). Ethnography Step by Step, 2nd Edition, Thousand Oaks, CA: Sage Publications.

Fuller, M., Healey, M., Bradely, A. and Hall, T. (2004). Barriers to learning: A Systematic Study of the Experience of Disabled Students at one university. Studies in Higher Education, 29(3), 303-318. Retrieved on 11 August, 2009 from EBSCOHost database.

Gewer, A. (2010). Improving quality and expanding the further education and training college system to meet the need for an inclusive growth path, Development Bank of Southern Africa.

Greyling, E. (2008). Students with disabilities`experiences of support and barriers to their development at Stellenbosch University, Thesis presented in partial fulfilment of the requirement for the degree of Master of Educational Psychology at Stellenbosch University.

Kapp, J. A. (1991). Children with problems: an orthopedagogical perspective, Pretoria: Van Schalk.

Kneedler, R. D. Hallahan, D. P. and Kauffaman, J.M. (1984). Special education for today, Englewood Cliff: Prentice Hall.

Leedy, P.D and Ormrod, J.E. (2005). Practical research planning and design, 8th edition, USA: Pearson Merril Prentice Hall.

Maxwell, A. (2005). Qualitative research designs: An interactive approach (Ed), Thousand Oak: Sage Publications. 
Merriam, S.B. (1998). Qualitative research and case study applications in education, San Francisco: Jossey-Bass Publishers.

Merriam, S.B. (2002). Qualitative research in practice: Examples for discussion and analysis, San Fransisco: Jossey-Bass Publishers.

Morrow, L.M. (1985). Retelling stories: A strategy for improving children`s comprehension, concept of story structure and oral language complexity, The Elementary School Journal, 85, 647-661.

Mugabe, M.J. (2011). National Skills Development Strategies of South Africa: Foundations of FET, EDAE128.

Naidoo, A. (2010). Students with Disabilities' Perceptions \& Experiences of the Disabilities Unit at the University of KwaZulu-Natal: Howard College Campus, Submitted in Partial Fulfilment of the Requirement for the Degree of Masters of Social Science.

Nsamenang, B. (2004). The intersection of traditional African Education with school learning. Psychology: An introduction, Cape Town: Oxford University Press.

Office of the Deputy President. (1997). White paper on an Integrated National Disability Strategy, Pretoria: Office of the Deputy President.

Ritchie, J., and Lewis, J. (2003). Qualitative research practice. A guide for social science students and researchers, Thousand Oaks, California: Sage Publications.

Terre Blanche, M. (2004). Poverty. In L. Swartz, C. de laRey, and N. Duncan (Eds), An Introduction, Cape Town: Oxford University Press.

Willing, C. (2001). Introducing qualitative research in psychology: Adventures in theory and method, Buckingham: Open University Press. 
